\title{
Developing programs of intercultural education, with regard to the inclusive education's values
}

\author{
Claudiu Marian Bunăiașu \\ University of Craiova, 13 A. I. Cuza Street, 200585, Craiova, Romania \\ E-mail address: claudiu_bunaiasu@yahoo.com
} Keywords: intercultural education, inclusive education, comprehensively approach the inclusive
education, education for all, intercultural curriculum

\begin{abstract}
Both the intercultural education and inclusive education represent dimensions of the "new education", which approach the values of European conscience and contemporary society's complex issue, as part of the intercultural communication and social inclusion. These dimensions have specific issues, but also convergence points, as far as the finalities, as well as the means of achieving are regarded. The programs of intercultural education represent this kind of means, which facilitate accomplishing "education for all" purposes. The research's premises analyze intercultural competences' development, in order to comprehensively approach the inclusive education and argues legitimacy and the opportunity of investigation. The second part of the article presents the research, regarding the topic's impact and the modalities in order to develop and implement the intercultural education programs, which approach the values of social inclusion. The main investigation tool is represented by the questionnaire, which has been applied to a sample of 100 subjects (didactic staff, students). After systematizing the results of the research, there have been revealed subjects' perceptions, efficient modalities and types of programs that promote inclusive education's values.
\end{abstract}

\section{INTRODUCTION}

Systematically promoting the intercultural values, thorugh formal and non-formal education, represents an educational solution to contemporary education's issues, generated by the social exclusion. The analysis of the social exclusion concept has generated different approaches, from definitions that exclusively take into consideration the phenomenon of some persons' nonintegration as part of social activities, to some individuals or cultural groups' inferiority, caused by political, cultural, socio-economical and educational reasons. Within the meaning of complex approaches, the social exclusion concept "may be comprehended as an accumulation of processes that are confluent with gradually disruptions as part of the center of economy, politics and society, which gradually distance and place persons, groups, communities and territories in a position of inferiority as part of the relation with centres of power, resources and dominant values" (Estivil, 2003, apud Arpinte, Baboi, Cace, Tomescu (Doboş)\&Stănescu, 2008).

The comprehensive approach of the inclusive education supposes above all adopting the vision of including this educational dimension as part of "education for all". By reducing the inclusive education to integration of children with special educational requirements, especially with regard to disabilities (with therapeutic approaches), it will not solve the major problems of social inclusion and assertion of the European conscience's desirable values and society's development. Education for all is based on inclusive education and has the following attributes: "quality education; efficiency; responsibility; pluri-disciplinarity; complex process; strategy in order to respect rights; emphasize of the human individual value" (Vrasmaş\&Vrasmaş, 2012).

According to this approach, the development of intercultural competences is accomplished within the meaning of asserting social performances as part the social inclusion field, regarding the persons presenting a social exclusion risk or the marginalised groups, as well as all those being part of multi-cultural communities. The inclusion capitalizes "diversity and differences with respect and 
thankfulness because, the greater the diversity, the richer our capacity to create new visions on life" (op cit, p. 40).

As part of the educational strategies documents, it has been emphasized the idea that ,all children must be part of the educational system, including those coming from linguistic, ethnic or cultural minorities, children being part of far or nomad groups, street or working children, children with disabilities or those gifted" (Education for all world forum, Dakar, 2000).

Starting from these preliminary analyses, we have consider it opportune and necessary to undertake a micro-research in order to reveal the role of intercultural education programs in promoting the values of inclusive education and to identify efficient modalities in order to develop them. The investigative approach has the characteristics of an impact study, as part of which there have been involved subjects possessing knowledge, experience and expertise as part of the intercultural education field (didactic staff teaching as part of the University and pre-University education, students attending Educational Sciences). The results of the micro-research are capitalized as part of the research project Development directions of the intercultural curriculum in Romania, from the perspective of the European dimension of education, undertaken as part of the POSDRU/159/1.5/S/136077 project "Romanian culture and European cultural models: research, synchronization, durability", whose beneficiary is the Romanian Academy. To this purpose, the impact study represents the foundation in order to elaborate a cross-curricular program of intercultural education, which will be experimentally tested.

The hypothesis of the micro-research is:

If the programs of intercultural education are based on the principles of comprehensive approach on inclusive education and didactic strategies of the intercultural curriculum, then these will be considered efficient means in order to develop intercultural competences and to facilitate the social inclusion.

\section{METHODOLOGY}

\subsection{OBJECTIVE}

The purposes of the micro-research are:

1. Analyzing subjects' opinions, regarding the relation between intercultural education and inclusive education.

2. Systematizing the types of intercultural education programs, focused on promoting the values of inclusive education.

3. Generating efficient modalities and tools in order elaborate and implement educational programs, developed based on the relation between intercultural education and inclusive education.

\subsection{PARTICIPANTS}

The sample of subjects has been selected based on the mixt sampling technique, for reasons regarding the character of a methodological research, in order to support the research project Development directions of the intercultural curriculum in Romania, from the perspective of the European dimension of education. The sample of 100 subjects has the following structure: 40 persons belonging to the didactic staff teaching as part of the pre-University education; 25 persons belonging to the didactic staff teaching as part of the University education; 35 students attending University of Craiova, Educational Sciences field.

\subsection{INSTRUMENT}

The tool used as part of the research is represented by the questionnaire, which includes 22 items grouped on criteria in order to operationalize the hypothesis and on specific purposes. Thus, there resulted the following thematic categories of the questionnaire: 1) the role of intercultural education and inclusive education, as part of the post-modern society and pupils' personal development (items 1-6); 2) types of intercultural education programs, focused on inclusive education's values and specific competences aimed by them (items 7-15); 3) specific modalities and 
tools in order to develop programs of intercultural education, based on purposes of the social inclusion (items 16-22).

Subjects' answers have been emphasized by conducting two focus-groups meetings (with didactic staff and students) and some individual interviews.

\section{RESULTS}

The results of the research have been achieved by: a) generalizing answers in favor of the variables indicated (by bringing together those situated on the assessment scales "to a large extent" and „to a very large extent” or those numbered with 1, 2 ranking values); b) systematizing relevant answers, regarding the open answers items or the focus-groups and individual interviews. To this extent, we have accomplished the following results, grouped on thematic categories:

1) The role of intercultural education and inclusive education, as part of the post-modern society and pupils' personal development: 1.1.) promoting European principles and values, as part of the cultural diversity with regard to the social inclusion (Arpinte, Baboi, Cace, Tomescu (Doboş) \& Stănescu, 2008; Cucoş, 2000; Dasen, Perregaux \& Rey, 1999; Demorgon, 2010); 1.2) facilitating comprehension in order to approach the inclusive education, through the relation between intercultural education and inclusive education (Vrasmaş\&Vrasmaş, 2008); 1.3) providing a consistent theoretical and methodological framework in developing some curricular models, in accordance with the European educational dimension (Banks\& Banks,1997, Bernard, 2005; Bunăiaşu, 201; Nedelcu, 2008; Potolea, 2002; Pinar, 1998); 1.4) adequating to European mental images, regarding the values of education and professionalization for a didactic career (Bernard, 2005; Strungă, 2014); 1.5) promoting good educational practices, as part of formal and non-formal contexts, within the meaning of multicultural communication and meta-communication, of social inclusion (Georgiu, 2010; Haddad, Manço\&Eckmann, 2009; Opran, Voinea\&Teodorescu, 2015; Smarandache\&Vlăduţescu, 2014).

Table 1. Percentage data regarding the indicator "the role of intercultural education and inclusive education"

\begin{tabular}{|l|c|c|c|c|c|}
\hline Groups & $\begin{array}{c}\text { Criterion } \\
\text { no. } 1\end{array}$ & $\begin{array}{c}\text { Criterion } \\
\text { no. 2 }\end{array}$ & $\begin{array}{c}\text { Criterion } \\
\text { no. } 3\end{array}$ & $\begin{array}{c}\text { Criterion } \\
\text { no. } 4 .\end{array}$ & $\begin{array}{c}\text { Criterion } \\
\text { no. 5 }\end{array}$ \\
\hline $\begin{array}{l}\text { Pre-University } \\
\text { didactic staff }\end{array}$ & $77,50 \%$ & $52,50 \%$ & $57,50 \%$ & $55 \%$ & $75 \%$ \\
\hline $\begin{array}{l}\text { University } \\
\text { didactic staff }\end{array}$ & $80 \%$ & $76 \%$ & $72 \%$ & $76 \%$ & $84 \%$ \\
\hline Students & $74,28 \%$ & $51,42 \%$ & $54,28 \%$ & $60 \%$ & $77,14 \%$ \\
\hline
\end{tabular}

2) Types of intercultural education programs, based on inclusive education's values:

2.1.) educational programs, as part of the curriculum at school's decision; 2.2.) educational programs at school institution's level; 2.3) programs of educational partnership, within the meaning of zonal, national and European level; 2.4) educational programs, with extern financing; 2.5) programs of social and psycho-pedagogical assistance, dedicated to children presenting social exclusion risk. 
Table 2. Percentage data regarding the indicator "types of programs of intercultural education, based on the inclusive education's values"

\begin{tabular}{|l|c|c|c|c|c|}
\hline Groups & $\begin{array}{c}\text { Criterion } \\
\text { no. 1 }\end{array}$ & $\begin{array}{c}\text { Criterion } \\
\text { no. 2 }\end{array}$ & $\begin{array}{c}\text { Criterion } \\
\text { no. } 3\end{array}$ & $\begin{array}{c}\text { Criterion } \\
\text { no. } 4 .\end{array}$ & $\begin{array}{c}\text { Criterion } \\
\text { no. } 5\end{array}$ \\
\hline $\begin{array}{l}\text { Pre-University } \\
\text { didactic staff }\end{array}$ & $67,50 \%$ & $77,50 \%$ & $80 \%$ & $82,50 \%$ & $62,50 \%$ \\
\hline $\begin{array}{l}\text { University } \\
\text { didactic staff }\end{array}$ & $72 \%$ & $76 \%$ & $80 \%$ & $84 \%$ & $76 \%$ \\
\hline Students & $74,28 \%$ & $77,14 \%$ & $71,42 \%$ & $82,85 \%$ & $68,57 \%$ \\
\hline
\end{tabular}

3) Specific competences aimed through these educational programs: 3.1) competences in order to analyze the membership culture and to comprehend the cultural alterity; 3.2) competences of intercultural communication; 3.3) capitalizing the cultural and intercultural empathy, as part of multicultural contexts; 3.4 ) competences in order to comprehend social needs and needs of adequate networking with persons with special requirements or presenting a social exclusion risk.

Table 3. Percentage data regarding the indicator "competences specific to programs of intercultural education, based on inclusive education's values"

\begin{tabular}{|l|c|c|c|c|}
\hline Groups & Criterion no. 1 & Criterion no. 2 & Criterion no. 3 & Criterion no. 4. \\
\hline $\begin{array}{l}\text { Pre-University } \\
\text { didactic staff }\end{array}$ & $65 \%$ & $77,50 \%$ & $52,50 \%$ & $77,50 \%$ \\
\hline $\begin{array}{l}\text { University } \\
\text { didactic staff }\end{array}$ & $76 \%$ & $88 \%$ & $76 \%$ & $84 \%$ \\
\hline Students & $71,42 \%$ & $85,71 \%$ & $74,28 \%$ & $65,71 \%$ \\
\hline
\end{tabular}

4) Modalities and tools in order to develop programs of intercultural education, based on social inclusion's purposes: 4.1.) expanding the percentage of intercultural education activities, as part of the school programs and institutional programs; 4.2) applying different tools in order to analyze the educational needs of pupils aimed as part if the social inclusion process (Voiculescu, 2004); 4.3) elaborating educational programs, within the meaning of the paradigm of emotional learning pedagogy (Bădescu, 2014; Goleman, 1995); 4.4) applying principles and strategies of the integrated curriculum, as part of the planning and deployment of intercultural education's activities (Bunăiaşu, 2011; Potolea, 1983; Potolea\&Manolescu, 2005); 4.5) using strategies of interactive training, as part of multicultural groups (Oprea, 2008).

Table 4. Percentage data regarding the indicator "modalities and tools in order to develop programs of intercultural education"

\begin{tabular}{|l|c|c|c|c|c|}
\hline Groups & $\begin{array}{c}\text { Criterion } \\
\text { no. 1 }\end{array}$ & $\begin{array}{c}\text { Criterion } \\
\text { no. 2 }\end{array}$ & $\begin{array}{c}\text { Criterion } \\
\text { no. } 3\end{array}$ & $\begin{array}{c}\text { Criterion } \\
\text { no. } 4 .\end{array}$ & $\begin{array}{c}\text { Criterion } \\
\text { no. 5 }\end{array}$ \\
\hline $\begin{array}{l}\text { Pre-University } \\
\text { didactic staff }\end{array}$ & $77,50 \%$ & $62,50 \%$ & $47,50 \%$ & $65 \%$ & $82,50 \%$ \\
\hline $\begin{array}{l}\text { University } \\
\text { didactic staff }\end{array}$ & $64 \%$ & $80 \%$ & $72 \%$ & $76 \%$ & $84 \%$ \\
\hline Students & $74,28 \%$ & $71,42 \%$ & $51,42 \%$ & $65,71 \%$ & $82,85 \%$ \\
\hline
\end{tabular}




\section{CONCLUSION}

The results accomplished involve a general analysis on two directions: a) analysis on relevance and significance of the data achieved, within the meaning of validating the microresearch's hypothesis; b) the results' effects on the research process, as part of the project in cadrul Proiectului Development directions of the intercultural curriculum in Romania, from the perspective of the European dimension of education.

The data achieved, by systematizing those with the higher frequency on the superior stages of the answers' intensity, confirm subjects' adhesion to: a) principles and values of the intercultural education and inclusive education; b) efficiency of the relation between the two educational dimensions; c) strategies specific to the intercultural curriculum, due to develop educational programs. To be noticed that, as far as the majority of answers is regarded, there haven't been recorded any significant differences between categories of subjects (at the level of only three variables), which have required a high degree of expertise in order to emphasize didactic implications: comprehensively approach the inclusive education, the paradigm of emotional learning pedagogy).

The results confirm the basic premise of the impact study, according to which the educational programs, based on actual principles of the inclusive education and on intercultural curriculum's didactic strategies, represent efficient means in order to develop intercultural competences and to facilitate social inclusion. These results will be capitalized as part of the research on intercultural curriculum issue, by supporting the audit activity and the cross-curricular program Social relations as part of the multicultural society.

„, This paper is suported by the Sectorial Operational Programme Human Resources Development (SOP HRD), financed from the European Social Fund and by the Romanian Government under the contract number SOP HRD/159/1.5/S/136077”.

\section{References}

[1] Arpinte, D., Baboi, A., Cace, S., Tomescu (Doboş), C.\&Stănescu, I. .(2008) Politici de incluziune socială. http://www.revistacalitateavietii.ro/2008/CV-3-4-2008/07.pdf

[2] Banks, J.A.\& Banks, C. (1997). Multicultural education. Boston: Allyn\&Bacon.

[3] Bădescu, I. (2003). Sincronism european şi cultură critică românească. Cluj-Napoca: Editura Dacia

[4] Bădescu, I. (2014). Neuroştiinţa şi calea spre pedagogia învăţării emoţionale. http://sociologiaazi.ro/

[5] Bernard, F. de (coord.). Europe, diversité culturelle et mondialisations. Actes I de l'Université de Mondialisations du GERM, Parc de La Villette, Juin 2003. Paris : L'Harmattan.

[6] Bunăiaşu, C.M. (2011). Proiectarea şi managementul curriculumului la nivelul organizaţiei şcolare. Bucureşti: Editura Universitară, pp. 222-262.

[7] Cucoş, C. (2000). Educaţia. Dimensiuni culturale şi interculturale. Iaşi: Editua Polirom.

[8] Dasen, P., Perregaux, C.\& Rey, M. (1999). Educaţia interculturală. Iaşi: Editura Polirom.

[9] Demorgon, J. (2010). Complexité des cultures et de l'interculturel. Paris: Economica.

[10] Georgiu, G. (2010). Comunicarea interculturală. Bucureşti: Editura Comunicare.ro.

[11] Goleman, D. (1995). Emotional Intelligence: Why It Can Matter More Than IQ. Bantam Books.

[12] Haddad, K., Manço, A.\& Eckmann, M. (coord). (2009). Antagonismes communautaires et dialogues interculturels. Paris: L'Harmattan. Nedelcu, A. (2008). Fundamentele educaţiei interculturale. Iaşi: Editura Polirom.

[13] Opran, E., Voinea, D.V., Teodorescu, M. International Letters of Social and Humanistic Sciences, 47 (2015), pp. 16-27.

[14] Oprea, C.L. (2008). Strategii didactice interactive. Bucureşti: Editura Didactică şi Pedagogică, R.A. 
[15] Pinar, W.F. (ed). (1998). Curriculum Toward New Identities. New York, Londra: Garland Publishing.

[16] Potolea, D. Revista de pedagogie, 8 (1983).

[17] Potolea, D. (2002). Conceptualizarea curriculum-ului. O abordare multidimensională. In: Păun, E. şi Potolea, D. (coord.). Pedagogie. Fundamentări teoretice şi demersuri aplicative. Iaşi: Editura Polirom.

[18] Potolea, D., Manolescu, M. (2005). Teoria şi practica evaluării educaţionale. M.Ed.C.: Proiectul pentru Învăţământul rural.

[19] Smarandache, F., Vlăduţescu, Ş. (2014). Revista de cercetare şi intervenţie socială, 46 (2014), pp. 243-254.

[20] Smarandache, F., Vlăduțescu, Ș. Social Sciences and Education Research Review, 1 (2014), pp. 44-62

[21] Strungă, A. C. (2014). Imaginile mentale europene şi identitate profesionalã în formarea cadrelor didactice: aplicaţii în domeniul învãțãmântului primar. București: Editura Universitară.

[22] Vrasmaş, E., Nicolae, S., Vrasmaş, T.(2008). Paşi spre educaţia incluzivă în România. Bucureşti: UNICEF.

[23] Vrasmaş, E. şi Vrasmaş, T. (2012). Educaţia incluzivă în grădiniţăa: dimensiuni, provocărişi soluţii. UNICEF, M.Ed.C.T.S, pp. 23,40. 